\title{
REFORMASI HUKUM TANAH DESA: REDEFINISI DAN PENGUATAN KEDUDUKAN
}

(Reform of Village Land Law: Redefinition and Strengthening)

\author{
Ayon Diniyanto \\ Insfre Indonesia \\ Jalan Kol. Hadijanto Nomor 117 Banaran, Sekaran, Gunungpati, Semarang \\ Email: ayondiniyanto24@gmail.com
}

Naskah diterima: 19 Agustus 2019; revisi: 8 November 2019; disetujui: 8 November 2019

\begin{abstract}
Abstrak
Desa di Indonesia merupakan kesatuan masyarakat yang dilindungi oleh konstitusi. Undang-Undang Dasar 1945 Pasal $18 \mathrm{~B}$ ayat (2) secara tidak langsung memuat kedudukan desa. Perlindungan dari konstitusi bukan merupakan jaminan desa terlepas dari permasalahan. Salah satu permasalahan yang ada di desa yaitu terkait dengan tanah desa. Tanah desa dilihat dari segi regulasi mempunyai problem. Problem terkait dengan tanah desa yaitu tentang definisi, jenis, dan kedudukan. Tidak ada kejelasan terkait dengan definisi, jenis, dan kedudukan tanah desa. Bahkan problem yang lebih krusial terjadi kerancuan pengertian antara tanah desa dengan tanah kas desa. Peraturan perundang-undangan tidak konsisten dalam menerapkan materi muatan tentang tanah desa. Oleh karena itu diperlukan penelitian untuk memecahkan problem tersebut. Penelitian ini menggunakan yuridis normatif dengan pendekatan undang-undang. Permasalahan terkait dengan regulasi tanah desa dapat diselesaikan dengan reformasi hukum tanah desa yang salah satunya meliputi redefinisi. Penguatan kedudukan tanah desa juga perlu dilakukan dalam rangka menjamin dan melindungi keberlanjutan tanah desa sebagai warisan leluhur. Diperlukan peran dari berbagai pihak seperti pemerintah, Dewan Perwakilan Rakyat, Pemerintah Desa, Masyarakat dan pihak-pihak lain agar reformasi hukum tanah desa dapat terealisasi.
\end{abstract}

Kata Kunci: reformasi, hukum, tanah desa

\begin{abstract}
Villages inIndonesia are community units protected by the constitution. Protection from the constitution is not a guarantee of the village regardless of the problem. One of the problems in the village is related to village land. Village land in terms of regulations has a problem. Problems related to village land are about definitions, types, and position. The laws and regulations are not consistent in applying content material on village land. Therefore research is needed to solve these problems. This research uses normative juridical with statutory approach. Problems related to village land regulation can be solved by reforming village land law, one of which includes redefinition. Strengthening village land status also needs to be done in order to guarantee and protect the sustainability of village land as ancestral heritage. The role of parties is needed so that the reform of village land law can be realized.
\end{abstract}

Keywords: reformation, law, village land 


\section{A. Pendahuluan}

Indonesia merupakan negara yang luas dengan susunan wilayah terdiri dari daerah provinsi dan di dalam daerah provinsi terdapat daerah kabupaten/kota. Begitu bunyi salah satu ayat dalam konstitusi yaitu UndangUndang Dasar 1945 Pasal 18. Selain terdiri atas wilayah-wilayah tersebut sebenarnya masih ada wilayah-wilayah terkecil di dalam daerah kabupaten/kota yaitu Desa dan Kelurahan. Konstitusi ternyata hanya menyinggung terkait dengan Desa yang merupakan salah satu wilayah terkecil dalam Negara Indonesia. Undang-Undang Dasar 1945 Pasal 18B ayat (2) menyatakan bahwa Negara mengakui dan menghormati kesatuan-kesatuan masyarakat hukum adat beserta hak-hak tradisionalnya sepanjang masih hidup dan sesuai dengan perkembangan masyarakat dan prinsip Negara Kesatuan Republik Indonesia, yang diatur dalam undang-undang. Desa dalam sejarahnya merupakan bagian seperti yang di definisikan oleh Undang-Undang Dasar 1945 Pasal 18B ayat $(2)^{1}$.

Penyebutan secara tidak langsung oleh konstitusi bahwa desa merupakan bagian dari kesatuan masyarakat adat yang telah ada sejak dulu sesuai dengan kondisi jumlah desa di Indonesia. Jumlah desa di Indonesia saat ini mencapai 75.436 desa $^{2}$ dan bisa terus bertambah. Banyaknya jumlah desa tersebut menandakan bahwa desa sudah menyeluruh berada di Indonesia. Berdasarkan sejarah, desa mempunyai penamaan tersendiri di berbagai wilayah. Misalnya di Sumatera selatan disebut sebagai Dusun atau Marga. Kemudian di Minang terkenal dengan Nagari, di Gorontalo disebut Kampung, dan di Nusa Tenggara Barat disebut sebagai Paer atau Pamusung ${ }^{3}$.

Akhir-akhir ini banyak yang tertarik mengkaji tentang desa, terlebih setelah lahirnya Undang-Undang Nomor 6 Tahun 2014 Tentang Desa. Kajian-kajian terkait dengan desa begitu masif. Banyaknya kajian-kajian tentang desa secara tersirat mempunyai makna bahwa di desa memang masih terdapat banyak permasalahan. Permasalahan yang sering mendapat perhatian di desa biasanya terkait dengan pemerintahan, regulasi ${ }^{4}$, anggaran $^{5}$ dan partisipasi masyarakat ${ }^{6}$.Selain permasalahan tentang tersebutyang sering mendapat perhatian, permasalahan tanah desa sesungguhnya harus diperhatikan sebagian bagian dari memperbaiki desa secara menyeluruh.Permasalahan yang mendasar dan jarang dikaji yaitu terkait dengan pengaturan tanah desa.Belum ada regulasi yang secara tegas mendefinisikan pengertian, jenis dan kedudukan tanah

M. Nur Alamsyah, "Memahami Perkembangan Desa di Indonesia," Jurnal Academica Fisip Untad Vol.03 No. 02 (2011): hlm. 649.

Badan Pusat Statistik, "Hasil Pendataan Potensi Desa (Pordes) 2018," Berita Resmi Statistik (2018): 1.

3 Nur Alamsyah, Op.Cit., "Memahami Perkembangan Desa di Indonesia," Jurnal Academica Fisip Untad Vol.03 No. 02 (2011): hlm. 649.

4 Rodiyah et al., "Village Bureaucracy Reform in Demoractic and Autonomy Era in Indonesia: Study of the Establishment of Laws and Regulations Method by IRR Model," South East Asia Journal of Contemporary Business, Economics and Law, Vol. 17, Issue 4 (December) (2018): hlm.1.

5 Chomariyah, Nurul Hudi, and Bambang Ariyanto, "Participation Principle On The 2014 Village Law In Coastal Village," International Journal of Business, Economics and Law, Vol. 10, Issue 4(Aug.) (2016): hlm. 33.

6 Sutrisno Purwohadi Mulyono, "Village Government Role in Building Participatory Democracy (Indonesian Experience)," International Journal of Business, Economics and Law, Vol. 3, Issue 3 (December), (2013): hlm. 20. 
desa. Permasalahan ini memang terlihat tidak begitu penting, namun dengan adanya perkembangan dunia properti yang semakin pesat, permasalahan tanah desa kedepan dapat diprediksi akan semakin rumit. Oleh karena itu diperlukan kejelasan tentang definisi, jenis, dan kedudukan tanah desa. Hal tersebut sangat diperlukan untuk diatur dalam regulasi yang kuat, sehingga pelaksana kebijakan akan lebih mudah memahami dan mampu bertindak secara benar khususnya dalam rangka pengelolaan tanah desa. Penelitian ini akan mengkaji terkait dengan bagaimana kedudukan tanah desa dan problem regulasi? serta bagaimana reformasi hukum tanah desa dalam rangka redefinisi dan penguatan kedudukan tanah desa?

\section{B. Metode Penelitian}

Penelitian hukum terdiri dari yuridisnormatif, yuridis-sosiologis, dan yuridisempiris. Penelitian ini menggunakan yuridis-normatif dengan pendekatan undangundang (statute approach). Pendekatan undang-undang dilakukan dengan meneliti terkait peraturan perundang-undangan yang berkaitan dengan rumusan masalah Peraturan perundang-undangan yang berkaitan dengan rumusan masalah yaitu peraturan perundang-undangan yang mengatur tentang tanah desa diantaranya Undang-Undang Nomor 6 Tahun 2014 Tentang Desa dan Peraturan Pemerintah Nomor 43 Tahun 2014 Tentang Peraturan Pelaksanaan Undang-Undang Nomor 6 Tahun 2014 Tentang Desa, Peraturan Menteri Dalam Negeri
Nomor 4 Tahun 2007 Tentang Pengelolaan Kekayaan Desa, dan Peraturan Menteri Dalam Negeri Nomor 1 Tahun 2016 Tentang Pengelolaan Aset Desa. Empat peraturan perundang-undangan tersebut akan menjadi objek kajian dan akan dikritisi. Tetapi ada dua peraturan inti yang akan menjadi objek kajian utama yaitu Undang-Undang Nomor 6 Tahun 2014 Tentang Desa dan Peraturan Menteri Dalam Negeri Nomor 1 Tahun 2016 Tentang Pengelolaan Aset Desa.

\section{Pembahasan}

\section{Kedudukan Tanah Desa dan Problem Regulasi}

Kedudukan tanah desa relatif kurang menjadi perdebatan di dalam khalayak umum, padahal kedudukan tanah desa sangat penting mengingat fungsi dari tanah desa. Kedudukan tanah desa secara umum dapat dilihat sebagai aset desa yang masuk dalam kategori kekayaan desa, aset dan kekayaan desa tentu mempunyai fungsi yang signifikan. Beberapa fungsi dari kekayaan desa berupa tanah desa seperti menjadi Pendapatan Asli Desa (PADes), untuk kepentingan umum, dan dapat sebagai bagian untuk memberikan pendapatan perangkat desa. Fungsi yang besar tersebut terkait dengan tanah desa dalam kenyataannya tidak didukung dengan regulasi yang sempurna dalam hal definisi dan kedudukan tanah desa. Sampai dengan saat ini belum ada regulasi yang secara jelas, rinci, dan konkrit mengatur tentang tanah desa dan didalamnya termuat pengertian, serta jenisjenis tanah desa.

Zaka Firma Aditya dan Rizkisyabana Yulistyaputri, "Romantisme Sistem Hukum di Indonesia: Kajian atas Kontribusi Hukum Adat dan Hukum Islam terhadap Pembangunan Hukum di Indonesia," Jurnal RechtsVinding: Media Pembinaan Hukum Nasional Vol. 8 No. 1 April (2019): hlm. 40. 
Regulasi yang dimaksud diantaranya Undang-Undang Nomor 6 Tahun 2014 Tentang Desa atau disebut Undang-Undang Desa dan Peraturan Menteri Dalam Negeri Nomor 1 Tahun 2016 Tentang Pengelolaan Aset Desaselanjutnya disebut Permendagri Nomor 1 Tahun 2016. Dua regulasi tersebut secara langsung dan tidak langsung menjadi problem dalam memberikan definisi dan kedudukan tanah desa. Sebelum lebih jauh melihat problem regulasi tersebut. Terlebih dahulu mencermati kedudukan tanah desa dari aspek regulasi yaitu Undang-Undang Desa Tentang Desa dan Permendagri Nomor 1 Tahun 2016.

\section{a. Kedudukan Tanah Desa menurut Regulasi saat ini}

Undang-Undang Nomor 6 Tahun 2014 Tentang Desa merupakan hukum tertinggi di bawah konstitusi yang mengatur tentang desa. Undang-Undang Desa telah mengatur desa secara komprehensif termasuk kekayaan desa yang di dalamnya terdapat tanah desa. Tanah desa di dalam Undang-Undang Desa masuk kategori aset desa. Pasal 76 ayat (1) Undang-Undang Desa menyatakan bahwa aset desa dapat berupa tanah kas desa, tanah ulayat, pasar desa, pasar hewan, tambatan perahu,bangunan desa, pelelangan ikan, pelelangan hasil pertanian, hutan milik desa, mata air milik desa,pemandian umum dan aset lainnya milik desa. Pengertian aset desa menurut Undang-Undang Desa adalah barang milik desa yang berasal dari kekayaan asli desa, dibeli atau diperoleh atas beban Anggaran Pendapatan dan Belanja Desa atau perolehan hak lainnya yang sah ${ }^{8}$. Artinya secara hukum tanah desa merupakan aset desa yang dimiliki secara mutlak oleh desa dan dalam Undang-Undang Desa tanah desa disebut sebagai tanah kas desa.

Apakah tanah kas desa sama dengan tanah desa? Pertanyaan tersebut harus dijawab untuk memberikan gambaran yang jelas antara tanah kas desa dengan tanah desa. Undang-Undang Desa tidak memberikan definisi terkait dengan tanah kas desa. Bahkan Undang-Undang Desa tidak menyinggung terkait tanah desa. Tidak disinggung dan diatur tanah desa dalam Undang-Undang Desa tentu sangat menarik, mengingat Undang-Undang Desa dianggap sebagai regulasi yang paling komprehensif dalam mengatur tentang desa. Pertanyaannya adalah, dimana pengaturan tanah kas desa dan tanah desa. Ada petunjuk terkait dengan pengaturan tanah kas desa dan tanah desa. Pasal 77 ayat (3) Undang-Undang Desa menyatakan bahwa pengelolaan kekayaan milik Desa sebagaimana dimaksud pada ayat (2) dibahas oleh Kepala Desa bersama Badan Permusyawaratan Desa berdasarkan tata cara pengelolaan kekayaan milik Desa yang diatur dalam Peraturan Pemerintah.

Ketentuan dalam Pasal 77 ayat (3) UndangUndang Desa seakan memberikan petunjuk bahwa pengaturan tanah kas desa dan tanah desa diatur dalam Peraturan Pemerintah. Peraturan Pemerintah yang terkait dengan Undang-Undang Desa adalah Peraturan Pemerintah Nomor 43 Tahun 2014 Tentang Peraturan Pelaksanaan Undang-Undang Nomor 6 Tahun 2014 Tentang Desa atau PP Pelaksana Undang-Undang Desa. PP Pelaksana Desa ternyata juga belum secara konkrit 
mengatur tentang tanah kas desa dan tanah desa. Bahkan dalam PP Pelaksana UndangUndang Desa lebih mengatur terkait dengan mekanisme pengelolaan kekayaan desa. Walaupun demikian, PP Pelaksana UndangUndang Desa ternyata juga memberikan petunjuk terkait dengan pengaturan tanah kas desa dan tanah desa secara konkrit. Pasal 110 ayat (2) PP Pelaksana Undang-Undang Desa menyatakan bahwapengelolaan kekayaan milik desa diatur dengan Peraturan Desa dengan berpedoman pada Peraturan Menteri.

Walaupun Undang-Undang Desa dan PP Pelaksana Undang-Undang Desa tersebut tidak secara konkrit mengatur tanah kas desa dan tanah desa. Ada hal yang dapat diambil dari dua regulasi diatas, khususnya PP Pelaksana Undang-Undang Desa. Bahwa pengelolaan kekayaan desa yang di dalamnya terdapat tanah kas desa diatur melalui Peraturan Menteri. Ada dua Peraturan Menteri yang terkait dengan pengelolaan aset atau kekayaan desa yang di dalamnya terdapat regulasi tentang tanah kas desa dan tanah desa yaitu Peraturan Menteri Dalam Negeri Nomor 4 Tahun 2007 Tentang Pedoman Pengelolaan Kekayaan Desa atau Permendagri Nomor 4 Tahun 2007 dan Permendagri Nomor 1 Tahun 2016.

Sebenarnya terdapat Peraturan Menteri Desa, Pembangunan Daerah Tertinggal, dan Transmigrasi yang menyinggung terkait dengan tanah desa serta tanah kas desa. Namun Peraturan Menteri Desa, Pembangunan Daerah Tertinggal, dan Transmigrasi Nomor 1 Tahun 2015 Tentang Pedoman Kewenangan Berdasarkan Hak Asal Usul dan Kewenangan
Lokal Berskala Desa atau selanjutnya disebut Permendes PDTT Nomor 1 Tahun 2015 tidak mengatur secara detail terkait dengan tanah desa atau tanah kas desa. Permendes PDTT Nomor 1 Tahun 2015 hanya mengatur terkait dengan kewenangan berdasarkan asal usul, kewenangan lokal berskala desa, serta tahap dan tatacara.

Permendagri Nomor 4 Tahun 2007 secara substansi hampir sama dengan Permendagri Nomor 1 Tahun 2016. Permendagri Nomor 4 Tahun 2007 sebenarnya menghadapi dilema. Apakah dengan adanya Permendagri Nomor 1 Tahun 2016 maka Permendagri Nomor 4 Tahun 2007 tidak berlaku? Mengingat dua peraturan tersebut secara substansi samasama mengatur kekayaan desa. Secara eksplisit memang dalam Permendagri Nomor 1 Tahun 2016 tidak menyatakan tidak berlakunya Permendagri Nomor 4 Tahun 2007. Namun dalam ketentuan umum Permendagri Nomor 1 Tahun 2016 secara tegas dinyatakan bahwa regulasi yang mengatur tentang pengelolaan aset desa harus berpedoman pada Permendagri Nomor 1 Tahun 2016 ${ }^{9}$. Diketahui bersama bahwa kekayaan desa merupakan bagian dari aset desa ${ }^{10}$. Jelaslah bahwa regulasi yang menjadi pedoman pengelolaan aset desa dalam hal ini adalah Permendagri Nomor 1 Tahun 2016.

Artinya kedudukan dan pengelolaan tanah desa secara teknis diatur dalam Permendagri Nomor 1 Tahun 2016. Pasal 1 ayat (26) Permendagri Nomor 1 Tahun 2016 menyatakan bahwa Tanah Desa adalah tanah yang dikuasai dan ataudimiliki oleh Pemerintah Desa sebagai salah satu sumberpendapatan asli desa

\footnotetext{
9 Lihat Ketentuan Penutup Pasal 50 Peraturan Menteri Dalam Negeri Nomor 1 Tahun 2016 tentang Pengelolaan Aset Desa.

10 Lihat Pasal 2 Peraturan Menteri Dalam Negeri Nomor 1 Tahun 2016 tentang Pengelolaan Aset Desa.
} 
dan/atau untuk kepentingan sosial. Tanah desa menurut Permendagri Nomor 1 Tahun 2016 merupakan aset desa yang berbentuk kekayaan desa. Tetapi penyebutannya bukan tanah desa melainkan tanah kas desa ${ }^{1}$. Artinya ada perbedaan pengertian antara tanah desa dalam Pasal 1 ayat (26) dan tanah kas desa dalam Pasal 2 ayat (2) huruf [a] Permendagri Nomor 1 Tahun 2016. Menurut Permendagri Nomor 1 Tahun 2016 tanah desa merupakan tanah yang dikuasai oleh desa sebagai sumber PADes dan kepentingan sosial. Adapun tanah kas desa merupakan kekayaan asli desa yang dapat berfungsi untuk memberikan PADes. Kemudian tanah desa menurut Permendagri Nomor 4 Tahun 2007 adalah tanah yang berupa bengkok, kuburan, dan titisara².

Tidak ada penyebutan tanah kas desa masuk dalam tanah desa menurut Permendagri Nomor 4 Tahun 2007.Walaupun dapat diartikan bahwa tanah bengkok sama dengan tanah kas desa ${ }^{3}$. Tetapi tidak adanya penjelasan lebih lanjut yang menyatakan bahwa tanah bengkok adalah tanah kas desa dalam Permendagri Nomor 4 Tahun 2007. Kondisi tersebut masih menyebabkan ketidakjelasan antara tanah desa dengan tanah kas desa. Seharusnya Permendagri Nomor 4 Tahun 2007 konsisten menyatakan bahwa tanah desa meliputi tanah kas desa atau di dalam jenis kekayaan desa dijelaskan bahwa salah satu jenis kekayaan desa tanah bengkok bukan tanah kas desa ${ }^{4}$.

\section{b. Problem Regulasi Tanah Desa}

Telah diketahui bahwa kedudukan tanah desa dan tanah kas desa secara umum diatur dalam Undang-Undang Desa dan secara teknis diatur dalam Permendagri Nomor 1 Tahun 2016. Regulasi dalam Undang-Undang Desa tidak mengatur tentang definisi, jenis, dan kedudukantanah desa. Pengaturan terkait dengan tanah desa dan tanah kas desa diatur dalam Permendagri Nomor 1 Tahun 2016 dan Permendagri Nomor 4 Tahun 2007. Berdasarkan dua Permendagri tersebut justru dapat dikatakan bahwa ada perbedaan mendasar terkait dengan tanah desa dan tanah kas desa. Tanah desa tidak meliputi tanah kas desa, begitu juga sebaliknya tanah kas desa bukan merupakan tanah desa. Kondisi tersebut tentu tidak tepat karena dapat menimbulkan berbagai permasalahan. Permasalahan yang dapat ditimbulkan apabila tidak ada kejelasan terkait dengan pengertian tanah desa dan tanah kas desa diantaranya terkait pengelolaan dan pemanfaatan serta status hukum.

Melihat dari dua Permendagri tersebut maka pemanfaatan dan status hukum antara tanah desa dengan tanah kas desa berbeda. Tanah desa dapat dimanfaatkan untuk menjadi sumber PADes dan kepentingan umum. Adapun tanah kas desa lebih cenderung berfungsi sebagai PADes.

11 Lihat Pasal 2 Peraturan Menteri Dalam Negeri Nomor 1 Tahun 2016 tentang Pengelolaan Aset Desa.

12 Lihat Pasal 1 ayat (10) Peraturan Menteri Dalam Negeri Nomor 4 Tahun 2007 tentang Pengelolaan Kekayaan Desa.

13 Rusliana dan Sri Kusriyah, "Implementasi Kebijakan Tukar Menukar Aset Desa Berupa Tanah Di Kabupaten Kendal (Studi Implementasi Permendagri Nomor 1 Tahun 2016 tentang Pengelolaan Aset Desa), Jurnal Hukum Khaira Ummah Vol. 12. No. 3 September, (2017): hlm. 666.

14 Lihat Pasal 1 ayat (10) dan Pasal 2 ayat (1) huruf [a] Peraturan Menteri Dalam Negeri Nomor 4 Tahun 2007 tentang Pengelolaan Kekayaan Desa. 
Walaupun secara asas tanah kas desa harus mewujudkan kepentingan umum. Tetapi mekanisme pemanfaatan untuk kepentingan umum berbeda antara tanah desa dengan tanah kas desa. Tanah desa dapat langsung dimanfaatkan untuk kepentingan umum seperti kuburan. Adapun tanah kas desa akan sulit dimanfaatkan untuk kepentingan umum selain melalui pengelolaan berupa sewa, bangun guna atau sebagainya.

Jika kondisi tersebut tidak diperbaiki segera maka problem terkait pertanahan di desa akan terjadi. Pemerintah Desa akan mengalami kesulitan manakala harus memanfaatkan tanah kas desa untuk PADes atau kepentingan umum. Apabila melihat regulasi sekarang maka Pemerintah Desa dapat cenderung untuk memanfaatkan tanah kas desa sebagai PADes daripada menjadikan tempat pemakaman (kuburan) yang merupakan kepentingan umum. Walaupun secara keadaan tempat pemakaman lebih penting dari PADes. Tetapi karena regulasi yang saat ini maka tentu Pemerintah Desa tidak dapat disalahkan. Kondisi demikian di kemudian hari dapat menimbulkan konflik terutama antara masyarakat desa dengan Pemerintah Desa. Oleh karena itu perlu redefinisi dan penguatan kedudukan antara tanah desa dan tanah kas desa.

Reformasi hukum pertanahan di desa harus dilakukan untuk memberikan jaminan kepastian hukum terhadap pemerintah desa dan masyarakat desa. Jaminan kepastian hukum tersebut sangat penting bagi pemerintah desa dalam mengambil kebijakan tentang pertanahan di desa. Masyarakat desa juga membutuhkan kepastian terkait kedudukan pertanahan di desa agar dapat memahami kondisi sehingga tidak menimbulkan problem dengan Pemerintah Desa

\section{Reformasi Hukum Tanah Desa dalam Rangka Redefinisi dan Penguatan Kedudukan Tanah Desa}

Problem tanah desa dan tanah kas seperti yang telah digambarkan memang terlihat biasa. Problem yang terletak pada definisi, jenis, dan kedudukan memang bukan perupakan problem yang substansial dari segi fungsi tanah desa dan tanah kas desa. Namun, apabila problem tersebut tidak segera diselesaikan dan ditegaskan terkait dengan definisi, jenis, dan kedudukan tanah desa. Problem tanah desa akan merambat pada level substansi yang didalamnya terdapat fungsi dari tanah desa. Reformasi hukum tanah desa merupakan salah satu solusi dalam menyelesaikan permasalahan tersebut. Peraturan perundang-undangan harus direformasi agar sesuai dengan maksud dari tanah desa. Reformasi tentang perundangundangan yang mengataur tanah desa dilakukan dengan tujuan untuk mencegah terjadinya multitafsir terhadap definisi, jenis, dan kedudukan tanah desa.

\section{a. Reformasi Hukum Tanah Desa yang Tepat}

Reformasi hukum tanah desa melalui reformasi peraturan perundang-undangan bukan merupakan perkara yang mudah. Ada dua aspek utama yang harus dilakukan dalam reformasi peraturan perudang-undangan terkait tanah desa. Dua aspek tersebut meliputi aspek formal dan materil. Aspek formal berkaitan dengan mekanisme atau prosedur reformasi peraturan perundangundangan. Adapun aspek materil berkaitan 
dengan reformasi substansi dalam materi peraturan perundang-undangan terkait tanah desa. Tahapan dalam reformasi hukum tanah desa tentu harus melalui tahapan aspek formal dan kemudian materil. Tanpa ada tahapan formal atau prosedur maka reformasi secara materil terkait hukum tanah desa tidak mungkin terlaksana. Oleh karena itu, dalam rangka reformasi hukum tanah desa, aspek formal harus dilasanakan terlebih dahulu, sebelum akhirnyamenuju pada aspek materil.

Aspek formal menekankan pada peran lembaga atau institusi yang mempunyai kewenangan untuk melakukan perubahan peraturan perundang-undangan atau reformasi hukum tanah desa. Reformasi hukum tanah desa yang berbentuk undangundang tentu membutuhkan peran utama dari Dewan Perwakilan Rakyat dan Pemerintah sebagai lembaga pembentuk kebijakan di level undang-undang. Tanpa ada kemauan dari lembaga tersebut untuk melakukan reformasi makareformasi hukum tanah di tingkat undang-undang tidak mungkin akan dilaksanakan. Hal tersebut juga berlaku pada hierarki peraturan perundang-undangan dibawahnya. Lembaga yang berwenang melakukan reformasi hukum tanah akan menyesuaikan dengan kewenangan yang dimiliki. Pemerintah selain dapat melakukan reformasi bersama Dewan Perwakilan Rakyat terkait level undang-undang. Pemerintah secara sendiri juga dapat melakukan reformasi terhadap Peraturan Pemerintah yang berkaitan dengan hukum tanah desa. Di level kementerian juga sama, Kementerian Dalam Negeri dapat melakukan perubahan peraturan perundang-undangan hukum terhadap Permendagri Tentang Aset Desa yang didalamnya memuat hukum tanah desa.

Aspek materil lebih menekankan pada substansi yang perlu di reformasi dalam hukum tanah desa. Konteks reformasi hukum tanah secara materil dapat dilakukan setelah melalui aspek formal. Reformasi hukum tanah secara substansi harus mengutamakan materi muatan yang perlu direformasi. Materi muatan yang tidak sesuai dan membutuhkan perbaikan harus dilakukan reformasi agar menjadi lebih baik. Stuffenbow Theory juga berlaku dalam reformasi substansi hukum tanah desa ${ }^{15}$. Materi muatan yang direformasi harus tidak bolehbertentangan dengan materi muatan diatasnya. Perubahan Permendagri Tentang Aset Desa tidak boleh bertentangan dengan PP Pelaksana Undang-Undang Desa. Begitu juga dengan perubahan PP Pelaksana Undang-Undang Desa tidak boleh bertentangan dengan Undang-Undang Desa.

Ada setidaknya empat peraturan perundang-undangan yang harus dilakukan perubahan terkait pengaturan tentang tanah desa. Empat peraturan perundang-undangan tersebut diantaranya (1) Undang-Undang Desa; (2) PP Pelaksana Undang-Undang Desa; (3) Permendagri Nomor 1 Tahun 2016; dan (4) Permendagri Nomor 4 Tahun 2007. Empat peraturan tersebut harus mengatur secara tegas dan jelas terkait dengan tanah desa. Oleh karena itu reformasi hukum tanah desa dapat dimulai dengan mereformasi peraturan perundang-undangan. Reformasi hukum tanah desa yang pertama yaitu terhadap UndangUndang Desa sebagai peraturan perundang- 
undangan yang mengatur tentang desa secara umum dan komprehensif. Perubahan Undang-Undang Desa harus dilakukan dalam rangka reformasi hukum tanah desa. UndangUndang Desa harus memuat definisi, jenis, dan kedudukan tanah desa secara jelas dan tegas. Pengaturan tanah desa dalam UndangUndang Desa tidak boleh menyebabkan multitafsir seperti saat ini. Pengertian ganda terkait tanah desa yang membingungkan dengan tanah kas desa juga harus ditiadakan.

Undang-Undang Desa dalam Ketentuan Umum misalnya harus dengan tegas menyatakan bahwa tanah desa merupakan kekayaan desa berbentuk tanah dengan dibuktikan surat-surat yang menyatakan milik desa. Ketentuan tentang tanah desa seperti itu jelas sangat tegas dan umum. Ketentuan tersebut tepat untuk diatur dalam UndangUndang Desa. Kondisi itu memberikan kemudahan ketika Undang-Undang Desa menyebutkan jenis-jenis aset desa. Artinya Undang-Undang Desa hanya menyebutkan jenis-jenis aset desa seperti (a) tanah desa; (b) tanah ulayat, pasar desa, pasar hewan, tambatan perahu,bangunan desa, pelelangan ikan, pelelangan hasil pertanian, hutan milik desa, mata air milik desa, pemandian umum, dan aset lainnya milik desa.Mengingat dalam ketentuan umum tentang tanah desa telah dijelaskan maka dalam penyebutan jenis-jenis aset desa tidak akan ada multitafsir terkait dengan tanah desa. Penafsiran terhadap tanah desa akan tertuju pada tanah yang dimiliki desa dengan bukti-bukti.

Ketika terjadi sengketa tanah antara pemerintah desa dengan masyarakat desa terkait dengan apakah tanah yang menjadi sengketa merupakan tanah desa atau tanah umum yang dapat dimiliki masyarakat.
Sangat mudah untuk menemukan solusi yaitu dengan memberikan bukti berupa surat-surat tentang kepemilikan tanah tersebut. Apabila Pemerintah Desa mampu membuktikan bahwa tanah tersebut merupakan milik desa dengan adanya bukti surat yang menyatakan tanah itu milik desa. Tanah tersebut tentu otomatis merupakan tanah desa yang tidak lain adalah kekayaan desa dengan bentuk tanah. Namun, apabila Pemerintah Desa tidak mampu membuktikan bahwa tanah tersebut milik desa (tidak mempuyai suratsurat) dapat dikatakan tanah tersebut bukan tanah desa. Keadaan ini akan mempermudah pemanfaatan fungsi tanah. Jika bukti suratsurat menyatakan tanah tersebut milik desa maka tanah tersebut dapat dimanfaatkan oleh desa untuk kepentingan umum atau memberikan PADes. Tetapi, jika tidak ada bukti yang menyatakan bahwa tanah tersebut bukan milik siapa-siapa maka tanah tersebut harus dikembalikan kepada negara.Masyarakat yang merasa dan dapat membuktikan bahwa tanah tersebut milik sebagian masyarakat atau perorangan, maka tanah tersebut tentu milik masyarakat atau perorangan sesuai dengan bukti yang ada. Pemerintah Desa tidak dapat mengklaim tanah tersebut sehingga tanah tersebut dapat dimanfaatkan oleh yang memilki.

Telah jelas bahwa reformasi hukum tanah desa yang dilakukan terhadap Undang-Undang Desa tidak hanya memberikan dampak bagi terjadinya tafsir tunggal terhadap tanah desa. Reformasi hukum tanah desa yang dilakukan terhadap Undang-Undang Desa juga mampu memberikan manfaat bagi Pemerintah Desa dan masyarakat desa dalam hal pemanfaatan tanah di desa. Selain itu, Pemerintah Desa juga akan mudah mengklaim atau menyatakan 
tanah desa selama memiliki bukti-bukti hukum.

Reformasi hukum tanah desa yang kedua yaitu terhadap PP Pelaksana Undang-Undang Desa. Adanya reformasihukum tanah desapada Undang-Undang Desa maka secara mutatis mutandis PP Pelaksana Undang-Undang Desa juga harus diubah atau direformasi. Perubahan PP Pelaksana Undang-Undang Desa yang berkaitan dengan tanah desa akan lebih mudah. Mengingat PP Pelaksana Undang-Undang Desa marupakan regulasi pelaksana, maka reformasi yang dilakukan hanya menyesuaikan Undang-Undang Desa. PP Pelaksana cukup menyesuaikan terkait dengan hukum tanah desa. PP Pelaksana dapat mengikuti ketentuan Undang-Undang Desa terkait tanah desa. PP Pelaksana lebih cenderung untuk fokus pada mekanisme pemanfaatan tanah desa.

Reformasi hukum tanah desa yang ketiga adalah dengan melakukan perubahan peraturan perundang-undangan yaitu Permendagri Nomor 1 Tahun 2016. Mengingat Pasal 110 ayat (2) PP Pelaksana UndangUndang Desa menyatakan bahwa Pengelolaan kekayaan milik desa diatur dengan Peraturan Desa dengan berpedoman pada Peraturan Menteri. Perubahan Permendagri Nomor 1 Tahun 2016 merupakan suatu keharusan dalam rangka mengatur tentang tanah desa secara teknis. Perubahan peraturan perundang-undangan yang perlu dilakukan dalam Permendagri Nomor 1 Tahun 2016 adalah terkait dengan jenis, dan kedudukan.
Dua hal tersebut harus diatur secara tegas dan konkrit dalam Permendagri Tentang Aset Desa. Kedepan Permendagri yang mengatur tentang aset desa diharapkan tidak inkonsisten tentang tanah desa seperti saat ini. Permendagri Nomor 1 Tahun 2016 dalam ketentuan umum menyatakan bahwa tanah desa merupakan tanah yang dimiliki desa untuk sumber pendapatan desa atau kepentingan umum $^{16}$. Artinya secara tidak langsung tanah desa merupakan aset desa yang berbentuk kekayaan desa. Tetapi dalam ketentuan selanjutnya yang menyatakan kekayaan desa tidak disebutkan tanah desa sebagai bagian dari kekayaan desa. Permendagri Nomor 1 Tahun 2016 menyatakan salah satu kekayaan asli desa adalah tanah kas desa ${ }^{17}$.

Kondisi tersebut jelas tidak konsisten dalam menyatakan kekayaan desa apakah tanah desa atau tanah kas desa. Mengingat dua hal tersebut dapat berbeda secara jenis. Tanah kas desa mungkin dapat dikatakan sebagai tanah desa, tetapi tanah desa tidak semua berbentuk tanah kas desa. Permendagri Nomor 4 Tahun 2007 menyatakan bahwa tanah kas desa tidak termasuk dalam pengertian tanah desa ${ }^{18}$. Kedepan inkonsistensi seperti itu tidak diperlukan lagi atau ditiadakan. Definisi tanah desa harus konsisten seperti yang tertuang dalam Undang-Undang Desa. Oleh karena itu dalam Permendagri Tentang Pengelolaan Aset Desa kedepan harus mengatur tentang jenis, dan kedudukan tanah desa. Ketentuan Umum tentang tanah desa dalam Permendagri Tentang Pengelolaan Aset Desa harus sama

16 Lihat Pasal 1 ayat (26) Peraturan Mentei Dalam Negeri Nomor 1 Tahun 2016 Ttntang Pengelolaan Aset Desa.

17 Lihat Pasal 2 ayat (2) huruf [a] Peraturan Menteri Dalam Negeri Nomor 1 Tahun 2016 tentang Pengelolaan Aset Desa.

18 Lihat Pasal 1 ayat (10) Peraturan Menteri Dalam Negeri Nomor 4 Tahun 2007 tentang Pedoman Pengelolaan Kekayaan Desa. 
dengan Ketentuan Umum seperti di UndangUndang Desa yang telah di reformasi.

Permendagri Tentang Pengelolaan Aset Desa harus mengatur terkait dengan jenis dan kedudukan tanah desa. Pengaturan jenis tanah desa dalam Permendagri Tentang Pengelolaan Aset Desa seperti menyebutkan jenis dari tanah desa. Contohnya: tanah desa adalah tanah yang berada di desameliputitanah kas desa, tanah bengkok, hutan desa, kuburan, lapangan, dan titisari. Penyebutan jenis tanah desa tersebut tentu bertujuan untuk mempermudah Pemerintah Desa dan masyarakat desa dalam mengidentifikasi tanah desa. Artinya tanpa dilakukan pembuktian kepemilikan, masyarakat sudah dapat mengidentifikasi bahwa suatu tanah merupakan tanah desa apabila disebut masyarakat sebagai tanah kas desa, tanah bengkok, hutan desa, kuburan, lapangan dan titisari. Terkait dengan hutan desa yang masuk dalam tanah desa dikarenakan hutan desa merupakan bagian dari tanah desa. $\mathrm{Hal}$, itu mengingat hutan desa merupakan bagian yang terintegrasi dengan kehidupan masyarakat desa, karena hutan desa mampu menjadi penyangga kehidupan desa atau sebagai paru-paru desa ${ }^{19}$.

Selanjutnya kedudukan tanah desa juga harus ditegaskan dalam Permendagri Tentang Pengelolaan Aset Desa. Kedudukan tanah desa harus dinyatakan bahwa tanah desa merupakan tanah abadi desa yang tidak boleh diambil oleh siapapun termasuk negara. Kedudukan tanah desa seperti itu sangat penting dengan melihat perkembangan zaman yang telah menghabiskan tanah untuk pemukiman. Tanah desa sebagai aset desa yang tidak lain merupakan warisan leluhur sebelum Indonesia merdeka. Misalnya saja tanah bengkok yang berasal dari tanah ganjaran, secara historis sudah ada sejak jaman kerajaan di Nusantara. Artinya tanah desa benar-benar warisan leluhur sebelum Indonesia merdeka ${ }^{20}$.

Ada kewajiban bagi desa untuk mempertahankan warisan leluhur tersebut. Jangan sampai terjadi pengambilalihan tanah desa oleh negara dengan alasan tanah negara seperti yang terjadi pada kasus tanah ulayat di Talonang Kabupaten Sumbawa Barat ${ }^{21}$. Salah satu cara mempertahankan tanah desa sebagai warisan leluhur adalah dengan menjadikan tanah desa sebagai tanah abadi milik desa yang tidak dapat diambil atau dikuasai oleh siapapun termasuk negara. Hanya desa yang secara otonom menguasai tanah desa untuk kepentingan umum desa.

\section{b. Redefinisi dan Penguatan Kedudukan Tanah Desa}

Telah diulas sebelumnya bahwa reformasi hukum tanah desa merupakan sesuatu yang harus dilakukan. Salah satu reformasi utama

19 Cokorda Dalem Dahana and Made Gde Subha Karma Resen, "Reflections of Law of Forestry Towards the Existence of VillageForest in Bali Province," International Journal of Business, Economics and Law, Vol. 11, Issue 4 (Dec.) (2016): hlm. 46.

20 Sigit Sapto Nugroho, Eksistensi Tanah Bengkok/Ganjaran sebagai Aset Desa Prespektif Undang-Undang Nomor 6 Tahun 2014 Tentang Desa(Studi Di Desa Ngujung, Maospati, Magetan, Jawa Timur)," Yustisia Merdeka Vol. Perdana Maret, (2015): hlm. 26-27.

21 Republika.co.id, "Mereka Sedang Perjuangkan Tanah Ulayat," republika.co.id, https://republika.co.id/berita/ koran/news-update/16/05/20/o7gu8612-mereka-sedang-perjuangkan-tanah-ulayat (diakses 18 Agustus 2019). 
hukum tanah desa adalah melakukan redefinisi tanah desa. Tanpa adanya redefinisi tanah desa maka reformasi hukum tanah desa tidak akan mempunya dampak yang signifikaan. Oleh karena itu redefinisi tanah desa dilakukan sebagai fondasi reformasi hukum tanah desa. Redefinisi tanah desa harus dilakukan dalam hukum yang tinggi. Melihat jenis dan hierarki peraturan perundang-undangan. UndangUndang merupakan regulasi yang tepat untuk direformasi dari segi definisi tanah desa. Mengingat memang hanya undangundang dalam hal ini Undang-Undang Desa yang mengatur terkait desa secara umum dan komprehensif. Keberhasilan redefinisi tanah desa dalam Undang-Undang Desa sesungguhnya telah memberikan arti bahwa setengah reformasi hukum tanah desa telah dilakukan. Artinya memang redefinisi tanah desa merupakan hal yang sangat penting dalam reformasi hukum tanah desa.

Setelah melakukan reformasi tanah desa baik dari definisi, jenis, dan kedudukan. Hal lain yang perlu diperhatikan adalah melakukan penguatan kedudukan tanah desa. Seperti yang telah disinggung sebelumnya bahwa ketersediaan lahan di kota dan desa yang semakin berkurang karena digunakan untuk pemukiman dan pendirian bangunan pemerintah pusat dan daerah merupakan ancaman terhadap tanah desa. Jangan sampai atas dasar kepentingan umum misalnya untuk membuat perumahan rakyat, gedung instansi pemerintah pusat atau daerah. Tanah desa menjadi aset yang harus dikorbankan ${ }^{22}$. Dalih kepentingan umum memang diperbolehkan tetapi desa juga mempunyai hak atas apa yang dimilki sebagai bagian dari warisan leluhur untuk dirawat dan dipelihara.

Tanah desa seperti yang dikatakan sebelumnya merupakan warisan leluhur yang harus dijaga dan dirawat serta dilestarikan. Menghindari ancaman-ancaman seperti yang telah disebutkan. Penguatan kedudukan tanah desa harus dilakukan. Ada hal penting yang perlu dilakukan dalam rangka penguatan kedudukan tanah desa yaitu dengan membuat kebijakan yang menyatakan bahwa tanah desa merupakan kekayaan desa dan tidak bisa diambil oleh siapapun termasuk daerah dan negara. Desa mempunyai otonomi untuk memiliki dan mengelola tanah desa dengan tidak boleh melepaskan tanah desa dari aset desa. Kebijakan tersebut sangat penting agar kedudukan tanah desa sangat kuat. Pertanyaannya adalah apakah tidak ada problem dalam kebijakan tersebut? Problem yang dihadapi, pertama, kemauan dalam membuat kebijakan yaitu negara. Apakah negara mempunyai kemauan untuk membuat kebijakan tersebut? Negara harus mempunyai dan segera membuat kebijakan tersebut dengan tujuan untuk menyelamatkan aset desa sebagai bagian dari warisan leluhur.

Kedua, problem yang dihadapi adalah terkait dengan tanah-tanah desa yang belum mempunyai bukti kempemilikan ${ }^{23}$. Problem ini sangat serius dan biasanya terjadi pada tanahtanah adat di desa ${ }^{24}$. Kemudian, tanah-tanah 
adat di desa tentu menjadi dilema apakah termasuk sebagai tanah desa atau menjadi tanah adat yang kepemilikannya berdasarkan masyarakat adat? Menghadapi problem tersebut solusi yang harus dilakukan adalah dengan musyawarah antara masyarakat adat setempat, pemerintah desa dan negara. Tiga pemangku kepentingan tersebut harus bermusyawarah apakah tanah-tanah adat dijadikan sebagai tanah desa atau terpisah dari tanah desa. Jika kesepakatan musyawarah memutuskan untuk menjadikan tanah adat bagian dari tanah desa, maka tanah tersebut segera didaftarkan ke kantor pertanahan untuk mempunyai bukti kepemilikan yang menyatakan tanah tersebut menjadi tanah desa.

Konsekuensinya status hukum tanah tersebut akan sama dengan tanah desa yang lain. Namun, apabila dalam musyawarah menyatakan bahwa tanah adat dalam suatu desa terpisah dari tanah desa maka tanah tersebut tidak dapat dikatakan sebagai tanah desa. Status hukum tanah tersebut berbeda dengan tanah desa melainkan berstatus sebagai tanah adat yang melekat pada adat istiadat setempat. Jika kebijakan terkait dengan tanah desa menjadi tanah abadi milik desa, maka tanah adat yang bukan termasuk tanah desa tidak dalam kebijakan tersebut.

Sebelum melakukan musyawarah maka perlu ada identifikasi dan inventarisasi kewenangan apakah tanah adat tersebut merupakan milik desa atau milik Pemerintah Daerah. Proses identifikasidan inventarisasi tersebut dapat dilakukan dengan berpedoman pada Peraturan Menteri Dalam Negeri Nomor
44 Tahun 2016 Tentang Kewenangan Desa atau Permendagri Nomor 44 Tahun $2016^{25}$. Apabila sudah teridentifikasi dan terinventarisasi bahwa tanah tersebut merupakan milik desa, proses selanjutnya untuk menentukan kedudukan tanah adat apakah menjadi tanah desa atau bukan. Jika hasil musyawarah menyatakan tanah adat menjadi milik desa maka harus segera dilegalkan menjadi tanah desa agar mempunyai kedudukan yang kuat.

Penguatan kedudukan tanah desa juga dilakukan dalam rangka untuk meminimalisir terjadinya penyalahgunaan tanah desa. Kasus tentang penyalahgunaan fungsi tanah desa di Indonesia sudah pernah terjadi. Kasus tersebut diantaranya yaitu penyalahgunaan fungsi tanah desa untuk di bangun bangunan permanen dan pemukiman, serta peralihan hak sewa. Menariknya yang terlibat dalam penyalahgunaan fungsi tanah desa tersebut adalah pemerintah desa, masyarakat dan oknum notaris setempat ${ }^{26}$. Penyalahgunaan fungsi tanah tersebut kedepan tidak boleh terjadi lagi. Dibutuhkan penguatan kedudukan tanah desa yaitu dengan membuat regulasi yang memberikan sanksi pidana bagi siapa saja melakukan penyalahgunaan fungsi tanah desa. Sanksi tersebut harus dimasukan dalam regulasi berupa Undang-Undang Desa.

Artinya ada dua kebijakan yang harus dilakukan dalam rangka penguatan kedudukan tanah desa. Pertama, kebijakan untuk melegalkan tanah desa menjadi tanah abadi milik desa dan dikelola secara otonom oleh desa. Kedua, kebijakan untuk memberikan sanksi pidana bagi orang atau badan hukum yang menyalahgunakan fungsi tanah desa.

\footnotetext{
$25 \quad$ Lihat Pasal 7 s.d. Pasal 13 Peraturan Menteri Dalam Negeri Nomor 44 Tahun 2016 Tentang Kewenangan Desa.

${ }^{26}$ Fattahillah Fahmi, "Penyalahgunaan Fungsi Tanah Kas Desa di Kecamatan Banguntapan Kabupaten Bantul Daerah Istimewa Yogyakarta," Lex Renaissance No. 2 Vol. 1 Juli,(2016): 149-150.
} 
Dua kebijakan tersebut dapat dibuat dengan memasukan rumusan penguatan (legalitas dan sanksi) di dalam Undang-Undang Desa. Apabila telah dirumuskan dua kebijakan tersebut dalam Undang-Undang Desa niscaya penguatan kedudukan tanah desa akan terealisasi.

\section{Penutup}

Problem regulasi tanah desa saat ini memang perlu diperbaiki khusunya yang menyangkut definisi, jenis, dan kedudukan tanah desa. Reformasi hukum tanah desa merupakan solusi terhadap problem tersebut. Reformasi hukum tanah desa dapat dilakukan dengan melakukan redefinisi tanah desa dalam peraturan perundang-undangan. Kemudian juga menegaskan kembali jenis-jenis tanah desa dalam peraturan perundang-undangan. Setelah melakukan reformasi hukum tanah desa melalui rediefinisi. Reformasi hukum tanah desa juga harus dilakukan dalam rangka penguatan kedudukan tanah desa. Ada dua reformasi hukum tanah desa dalam rangka penguatan kedudukan tanah desa. Pertama reformasi dari segi legilitas yaitu menjadikan tanah desa sebagai tanah abadi dan dikelola secara otonom oleh desa. Kedua pemberian sanksi terhadap siapa saja yang melakukan penyalahgunaan fungsi tanah desa.

Disarankan kepada pembuat kebijakan dalam hal ini Dewan Perwakilan Rakyat dan Pemerintah Pusat yang meliputi Menteri Dalam Negeri untuk segera melakukan reformasi hukum tanah desa khusunya terkait dengan redefinisi dan penguatan kedudukan tanah desa. Disarankan juga terhadap pemerintah desa dan masyarakat desa untuk kritis dan mengawasi jalannya hukum tanah desa. Bahkan diperlukan untuk mendesak pemegang kebijakan segera melakukan reformasi hukum tanah desa.

\section{Daftar Pustaka}

\section{Artikel dan Jurnal}

Aditya, Zaka Firma Aditya dan Rizkisyabana Yulistyaputri, "Romantisme Sistem Hukum di Indonesia: Kajian atas Kontribusi Hukum Adat dan Hukum Islam terhadap Pembangunan Hukum di Indonesia," Jurnal RechtsVinding: Media Pembinaan Hukum Nasional Vol. 8 No. 1 April (2019).

Alamsyah, M. Nur, "Memahami Perkembangan Desa di Indonesia," Jurnal Academica Fisip Untad Vol.03 No. 02 (2011).

Badan Pusat Statistik, "Hasil Pendataan Potensi Desa (Pordes) 2018," Berita Resmi Statistik (2018).

Chomariyah, Nurul Hudi, and Bambang Ariyanto, "Participation Principle On The 2014 Village Law In Coastal Village," International Journal of Business, Economics and Law, Vol. 10, Issue 4(Aug.) (2016).

Dahana, Cokorda Dalem and Made Gde Subha Karma Resen, "Reflections of Law of Forestry Towards the Existence of VillageForest in Bali Province," International Journal of Business, Economics and Law, Vol. 11, Issue 4 (Dec.) (2016).

Fahmi, Fattahillah, "Penyalahgunaan Fungsi Tanah Kas Desa di Kecamatan Banguntapan Kabupaten Bantul Daerah Istimewa Yogyakarta," Lex Renaissance No. 2 Vol. 1 Juli, (2016).

Konsorsium Pembaruan Agraria, "Reforma Agraria di Bawah Bayangan Investasi: Gaung Besar di Pinggiran Jalan," Catatan Akhir Tahun 2017 Konsorsium Pembaruan Agraria, (2017).

Mulyono, Sutrisno Purwohadi, "Village Government Role in Building Participatory Democracy (Indonesian Experience)," International Journal of Business, Economics and Law, Vol. 3, Issue 3 (December), (2013).

Nugroho, Sigit Sapto Nugroho, Eksistensi Tanah Bengkok/Ganjaran sebagai Aset Desa Prespektif Undang-Undang Nomor 6 Tahun 2014 Tentang Desa (Studi Di Desa Ngujung, Maospati, Magetan, Jawa Timur)," Yustisia Merdeka Vol. Perdana Maret, (2015). 
Rodiyah, "Aspect Democracy in the Formation of Regional Regulation (Case Study the Formation of Regional Regulation about Education inPerspective Socio-Legal)," International Journal of Business, Economics and Law, Vol. 2, Issue 3 (June), (2013).

Rodiyah et al., "Village Bureaucracy Reform in Demoractic and Autonomy Era in Indonesia: Study of the Establishment of Laws and Regulations Method by IRR Model," South East Asia Journal of Contemporary Business, Economics and Law, Vol. 17, Issue 4 (December), (2018).

Rusliana dan Sri Kusriyah, "Implementasi Kebijakan Tukar Menukar Aset Desa Berupa Tanah Di Kabupaten Kendal (Studi Implementasi Permendagri Nomor 1 Tahun 2016 tentang Pengelolaan Aset Desa), Jurnal Hukum Khaira Ummah Vol. 12. No. 3 September, (2017).

\section{Internet}

Michelle Suliyanto, "Surat Keterangan Tanah Bekas Milik Adat," hukumproperty.com, https:// www.hukumproperti.com/pertanahan/suratketerangan-tanah-bekas-milik-adat/ (diakses 18 Agustus 2019).

Republika.co.id, "Mereka Sedang Perjuangkan Tanah Ulayat," republika.co.id, https:// republika.co.id/berita/koran/newsupdate/16/05/20/o7gu8612-mereka-sedangperjuangkan-tanah-ulayat (diakses 18 Agustus 2019).

Riza Multazam Luthfy, Sertifikat tanah dan masyarakat adat," beritagar.id, https:// beritagar.id/artikel/telatah/sertifikat-tanahdan-masyarakat-adat (diakses 18 Agustus 2019).

\section{Peraturan}

Undang-Undang Nomor 6 Tahun 2014 Tentang Desa.

Peraturan Pemerintah Nomor 43 Tahun 2014 Tentang Peraturan Pelaksanaan UndangUndang Nomor 6 Tahun 2014 Tentang Desa.

Peraturan Menteri Dalam Negeri Nomor 4 Tahun 2007 Tentang Pedoman Pengelolaan Kekayaan Desa.

Peraturan Menteri Desa, Pembangunan Daerah Tertinggal, dan Transmigrasi Nomor 1 Tahun 2015 Tentang Pedoman Kewenangan Berdasarkan Hak Asal Usul dan Kewenangan Lokal Berskala Desa.

Peraturan Menteri Dalam Negeri Nomor 1 Tahun 2016 Tentang Pengelolaan Aset Desa.

Peraturan Menteri Dalam Negeri Nomor 44 Tahun 2016 Tentang Kewenangan Desa 